\title{
Nucleotide Sequencing and SNP Detection of Toll-Like Receptor-4 Gene in Murrah Buffalo (Bubalus bubalis)
}

\author{
M. Mitra, ${ }^{1}$ S. Taraphder, ${ }^{1}$ G. S. Sonawane, ${ }^{2}$ and A. Verma ${ }^{2}$ \\ ${ }^{1}$ Department of Animal Genetics and Breeding, Faculty of Veterinary and Animal Sciences, \\ West Bengal University of Animal and Fishery Sciences, 37768 Kshudiram Bose Sarani, West Bengal, Kolkata 700037, India \\ ${ }^{2}$ Dairy Cattle Breeding Division, NDRI, Karnal-132001, Haryana, India \\ Correspondence should be addressed to S. Taraphder, subhash.taraphder@gmail.com
}

Received 22 November 2011; Accepted 15 December 2011

Academic Editors: A. J. Molenaar and O. N. Ozoline

Copyright (๑) 2012 M. Mitra et al. This is an open access article distributed under the Creative Commons Attribution License, which permits unrestricted use, distribution, and reproduction in any medium, provided the original work is properly cited.

Toll-like receptor-4 (TLR-4) has an important pattern recognition receptor that recognizes endotoxins associated with gram negative bacterial infections. The present investigation was carried out to study nucleotide sequencing and SNP detection by PCR-RFLP analysis of the TLR-4 gene in Murrah buffalo. Genomic DNA was isolated from 102 lactating Murrah buffalo from NDRI herd. The amplified PCR fragments of TLR-4 comprised of exon 1, exon 2, exon 3.1, and exon 3.2 were examined to RFLP. PCR products were obtained with sizes of 165, 300, 478, and 409 bp. TLR-4 gene of investigated Murrah buffaloes was highly polymorphic with $\mathrm{AA}, \mathrm{AB}$, and $\mathrm{BB}$ genotypes as revealed by PCR-RFLP analysis using Dra I, Hae III, and Hinf I REs. Nucleotide sequencing of the amplified fragment of TLR-4 gene of Murrah buffalo was done. Twelve SNPs were identified. Six SNPs were nonsynonymous resulting in change in amino acids. Murrah is an indigenous Buffalo breed and the presence of the nonsynonymous SNP is indicative of its unique genomic architecture. Sequence alignment and homology across species using BLAST analysis revealed 97\%, 97\%, 99\%, 98\%, and 80\% sequence homology with Bos taurus, Bos indicus, Ovis aries, Capra hircus, and Homo sapiens, respectively.

\section{Introduction}

India is of a fortune position of having the world's best breeds of buffaloes for milk production. Special attention has to be focused on Murrah breed of Buffalo whose breed average milk production is about $2200 \mathrm{~kg}$ per lactation. Buffalo contribute more than fifty percent milk to the total milk produced in India. However, due to increased prevalence of infections, the realization of their true genetic merit has been hampered. Among infectious diseases, mastitis, an inflammatory disease of the mammary gland generally caused by intramammary infections, is the most common, costly, and devastating disease in dairy animals. Therefore, attention needs to be focused to study the genes involved in disease resistance, especially for mastitis. Genes associated with immune responses of the mammary gland are potential markers because of their importance in mastitis. The tolllike receptor-4 (TLR-4) is an important pattern recognition receptor that recognizes endotoxins associated with gram negative bacterial infections $[1,2]$. Its role in pathogen recognition and subsequent initiation of the inflammatory and immune responses, and highly polymorphic nature in the bovine species, make it a suitable candidate gene for use in marker-assisted selection for enhancing disease resistance in dairy animals [3]. The TLR-4 gene coding region is $2526 \mathrm{bp}$ long consisting of 3 exons and is located on chromosome BTA 8. Bovine TLR4 has three exons, exon 1 includes coding base pairs 1-95, exon 2 consists of base pairs $96-260$, and exon 3 comprises base pairs $261-2526$. The whole genomic length is estimated to be approximately $11 \mathrm{~kb}$, of which the first intron comprises about $5 \mathrm{~kb}$ and the second is $3 \mathrm{~kb}$. Polymorphic studies and nucleotide sequencing of TLR-4 gene have been reported in cattle $[4,5]$. With the exception of the thesis by Sonawane [6], no such information is available in Murrah buffalo. Considering the importance of Murrah buffalo in milk production, the present study was undertaken to partially sequence the buffalo TLR- 4 gene and to detect SNP. 

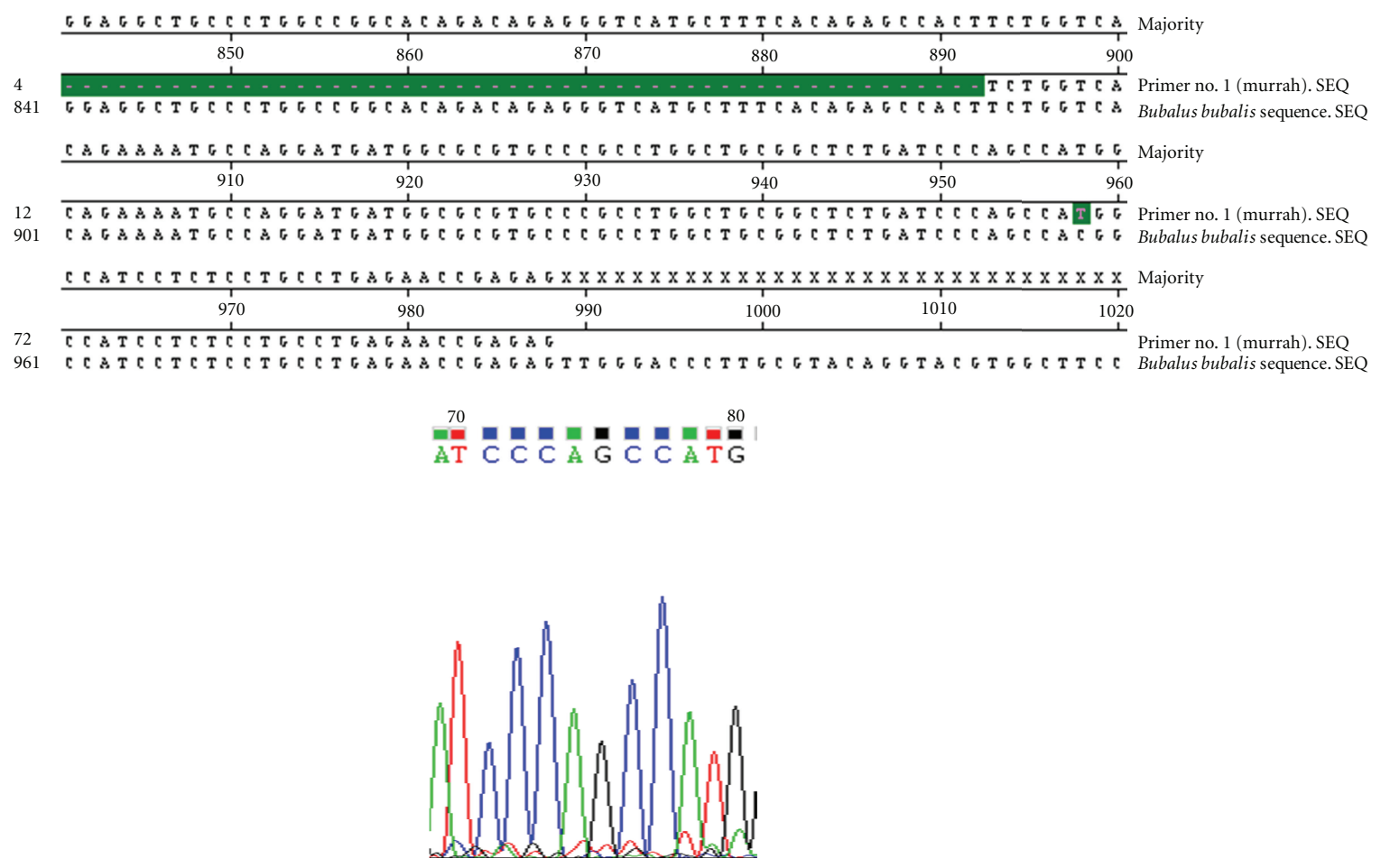

FIgURE 1: Clustal W alignment and chromatograph of exon 1 of TLR-4 gene in Murrah.

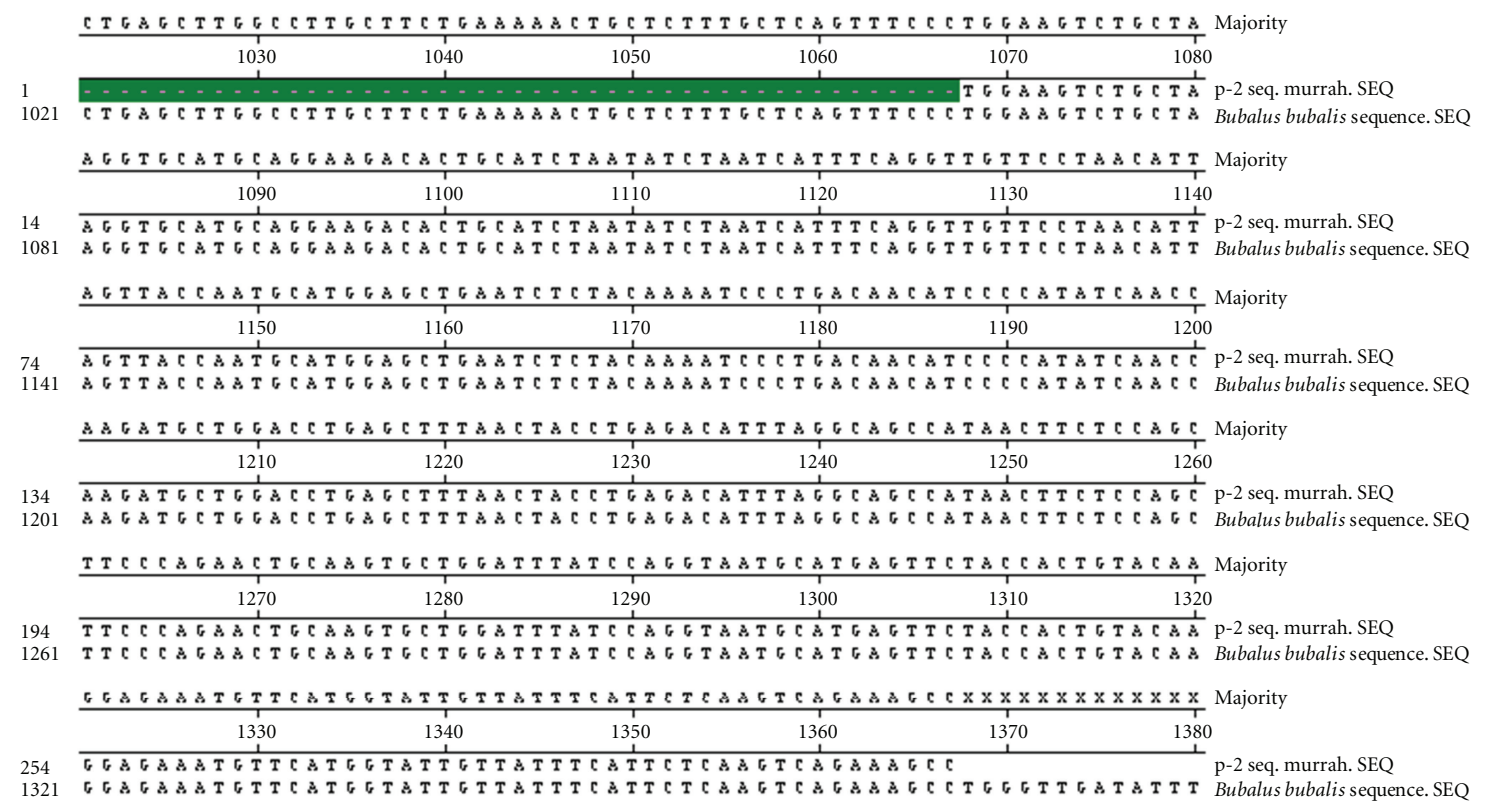

FIgURE 2: Clustal W alignment and chromatograph of exon 2 of TLR-4 gene in Murrah.

\section{Materials and Methods}

2.1. Experimental Animals and Sampling. The animals included in the present study were from the herd of Murrah Buffaloes maintained at cattle yard of National Dairy Research Institute, Karnal, Haryana, India. Blood samples were collected from 102 randomly selected lactating animals.
2.2. Isolation of Genomic DNA. Ten $\mathrm{mL}$ of blood was collected aseptically by jugular vein puncture in a sterile vacutainer tube containing $15 \%$ of $0.12 \mathrm{~mL}$ EDTA solution (Becton-Dickinson vacutainer). The samples were transported to the laboratory in an icebox and stored at $4^{\circ} \mathrm{C}$ till further processing for DNA isolation. The blood samples were centrifuged and DNA was isolated from the buffy coat 

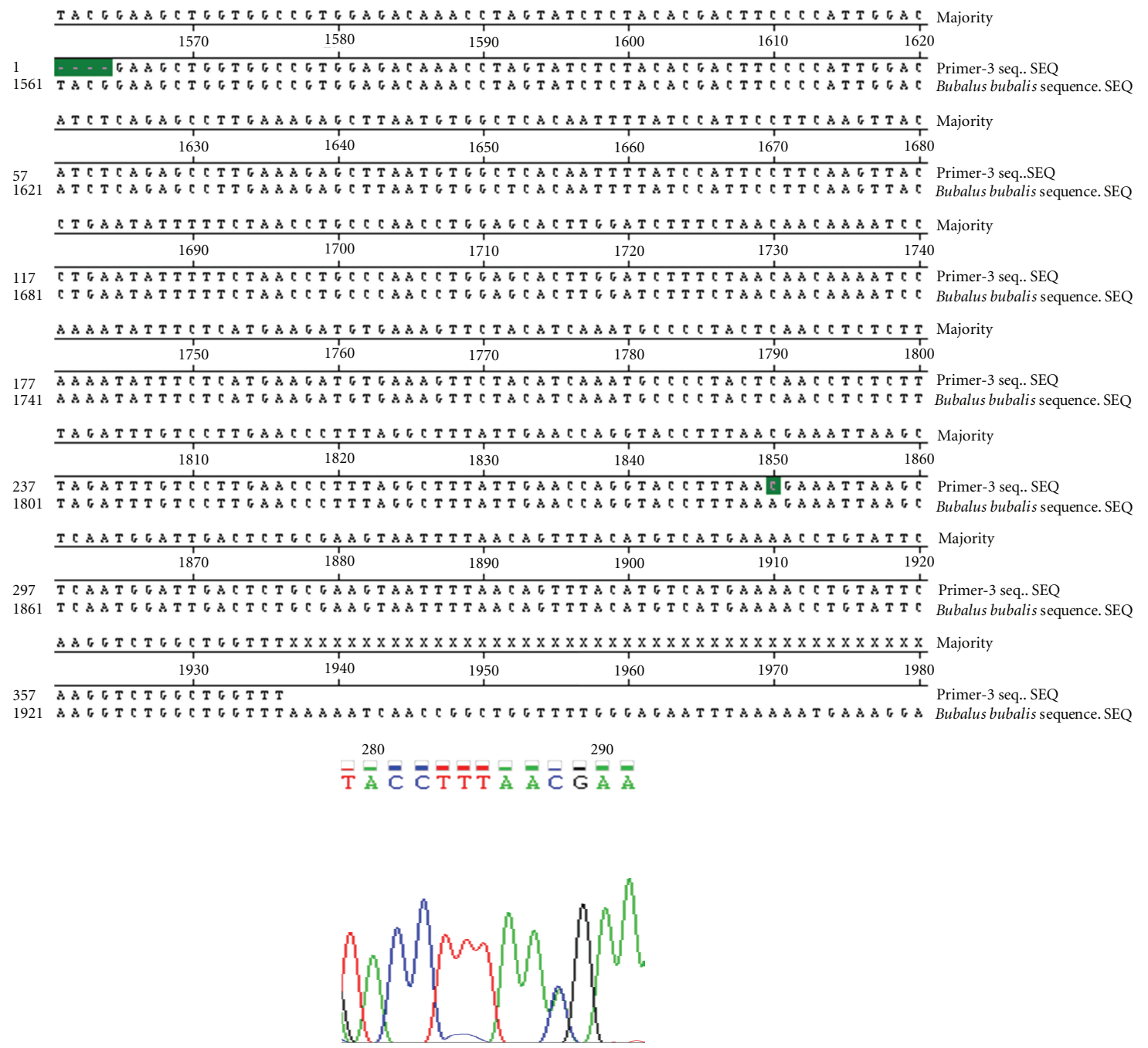

FIGURE 3: Clustal W alignment and chromatograph of contig 3.1 of TLR-4 gene in Murrah.

alone using phenol-chloroform method, as described by Sambrook et al. [7] with few modifications.

2.3. Quality, Purity, and Concentration of DNA. Quality of DNA was checked by electrophoresis by loading $2 \mu \mathrm{L}$ DNA on $0.8 \%$ agarose in horizontal minielectrophoresis unit using 1xTBE as running buffer at 30-40 volts for about one and a half hours. After electrophoresis, the gel was stained with ethidium bromide solution $(0.5 \mu \mathrm{g} / \mathrm{mL})$. The gel was photographed by Gel Documentation System and files stored.

Quality and quantity of DNA was estimated by spectrophotometer method. DNA $(2 \mu \mathrm{l})$ was dissolved in $98 \mu \mathrm{l}$ of double-distilled water and loaded into a $100 \mu \mathrm{l}$ cuvette. Optical density (OD) was determined at wavelengths $260 \mathrm{~nm}$ and $280 \mathrm{~nm}$ in a UV-Vis spectrophotometer against distilled water as blank sample. The ratio between $\mathrm{OD}_{260}$ and $\mathrm{OD}_{280}$ was calculated. The sample possessing a ratio of less than 1.7 and more than 2.0 was subjected to proteinase $\mathrm{K}$ digestion and DNA extracted with phenol chloroform isoamyl alcohol as described previously.

2.4. PCR-RFLP of TLR4 Gene. The primer pairs for exons 1 and 2 of TLR-4 gene were designed by using the primer 3 plus software, and primers 3 and 4 which are part of exon 3 were used as described by Sonawane [6]. Primers for TLR 4 Gene are as follows: Forward 5' ${ }^{\prime}$-CATGCTGATGATGATGGCGCGTG-3' and Reverse $5^{\prime}$-CGTACGATCACTGTACGCAAGG-3' for exon 1, Forward 5' -TTGTTCCTAACATTAGTTACC-3' and Reverse 5' CTGGATAAATCCAGCACTTGCAG-3' for exon 2, Forward 5'-GGCTGGTTTTGGGAGAATTT- $3^{\prime}$ and Reverse 5' TGTGAGAACAGCAACCCTTG-3' for exon 3.1, and Forward 5' -CCAGAGCCGATGGTGTATCT-3' and Reverse 5' CACTGAATCACCGGGCTTT-3' for exon 3.2.

For amplification, $25 \mu \mathrm{L}$ of PCR reaction was prepared by adding each primer, dNTPs, $\mathrm{MgCl}_{2}, 10 \times$ PCR assay buffer, DNA template, and Taq DNA polymerase. The amplification was carried out using a preprogrammed thermal cycler 

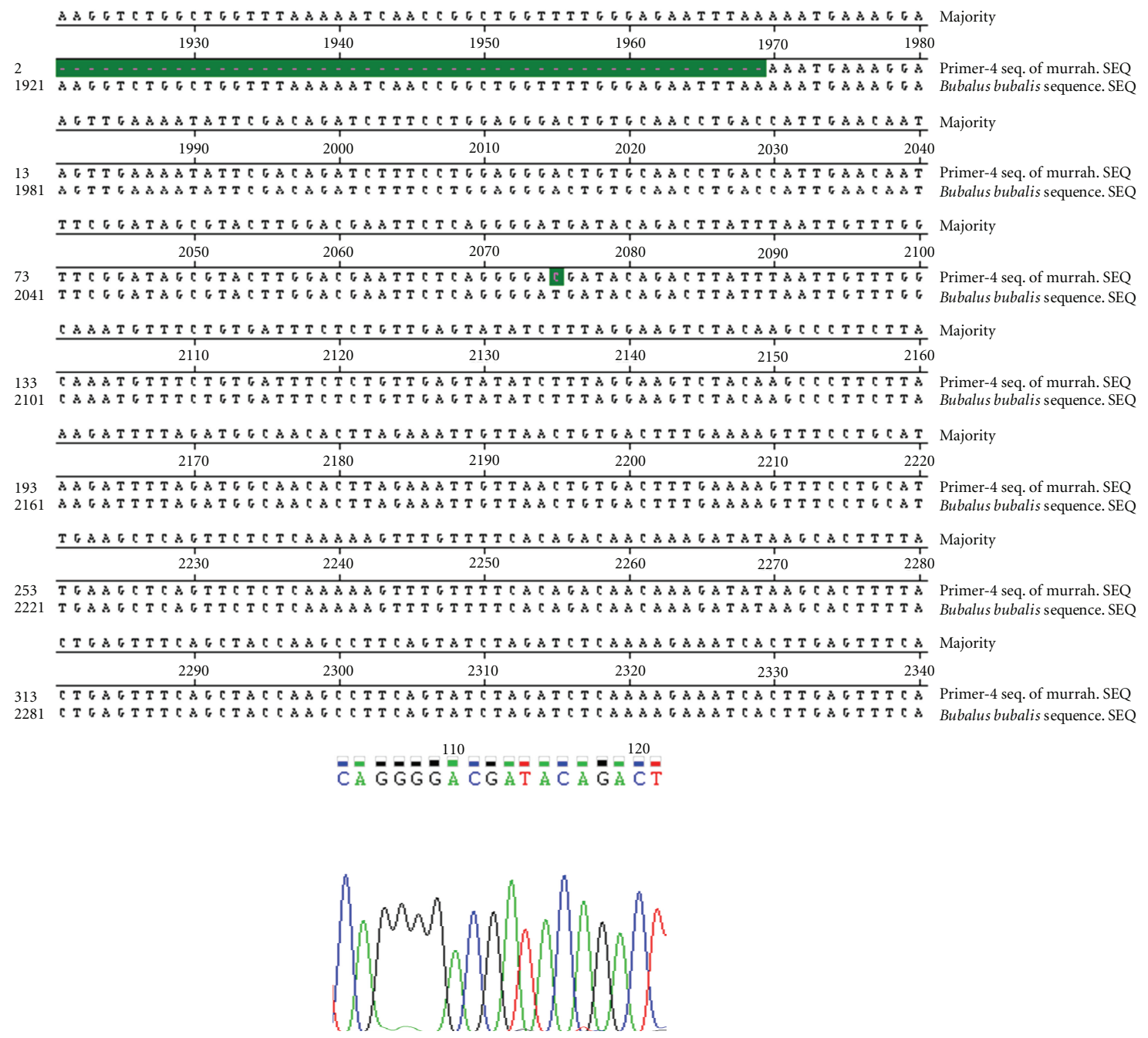

FIgUre 4: Clustal W Alignment and Chromatograph of Contig 3.2 of TLR-4 Gene in Murrah.

(Eppendrof Mastercycler) with the following conditions: initial denaturation of $2 \mathrm{~min}$ at $95^{\circ} \mathrm{C}$ followed by 35 cycles of denaturation at $94^{\circ} \mathrm{C}$, annealing at $55^{\circ} \mathrm{C}$ for primers 1 and 2, $54^{\circ} \mathrm{C}$ for primers 3 and 4 for $30 \mathrm{sec}$, extension at $72^{\circ} \mathrm{C}$ each of $1 \mathrm{~min} 30 \mathrm{sec}$ and lastly the final extension of $7 \mathrm{~min}$ at $72^{\circ} \mathrm{C}$. After PCR amplification, $5 \mu \mathrm{L}$ the PCR product was checked on a $1.5 \%$ agarose gel to verify the amplification of target region.

The amplified PCR fragments, namely, exon 1, exon 2, exon 3.2, and exon 3.2 of TLR 4 gene were

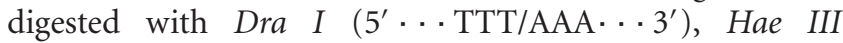
$\left(5^{\prime} \cdots \mathrm{GG} / \mathrm{CC} \cdot \cdots 3^{\prime}\right)$, Hind III $\left(5^{\prime} \cdots \mathrm{A} / \mathrm{AGCTT} \cdot \cdots 3^{\prime}\right)$, and Hinf $I\left(5^{\prime} \cdots\right.$ G/ANTC $\left.\cdots 3^{\prime}\right)$ restriction enzymes, respectively. The reaction mixture $(20 \mu \mathrm{L})$ for each enzyme was kept for incubated at $37^{\circ} \mathrm{C}$ for 4 hours. Restriction fragments were resolved on $2-3 \%$ agarose gel horizontal electrophoresis and visualized by ethidium bromide staining. The ethidium bromide was added to the agarose gel of $1 \mu \mathrm{L} / 100 \mathrm{~mL}$ of gel. The agarose gel electrophoresis was performed in $1 \mathrm{X}$ TBE buffer at 100 volts for 30, 60, and 90 minutes till complete separation and visualization of all fragments of RE-digested gene fragments, DNA ladder and PCR marker. The restriction-digested gene fragments were visualized on UV transilluminator and photographed with gel documentation system.

\section{Custom DNA Sequencing}

Amplified PCR products were subjected to custom DNA sequencing from both ends ( $5^{\prime}$ and $3^{\prime}$ ends). Representative samples from each of the variants obtained by RFLP analysis were also custom sequenced (Chromous Biotech Pvt. Ltd., Bangalore, India). Nucleotide sequences were visualized using Chromas (Ver. 1.45, http://www.techelysium.com.au/chromas.html). Sequence data were edited using the Editseq program, and multiple sequence alignments were performed with MegAlign program of LASERGENE software, respectively (DNASTAR, Inc, Madison WI, USA). The forward and reverse sequences for each PCR fragment were assembled to form contigs of the respective region. The TLR- 4 gene sequence of Murrah was compared 

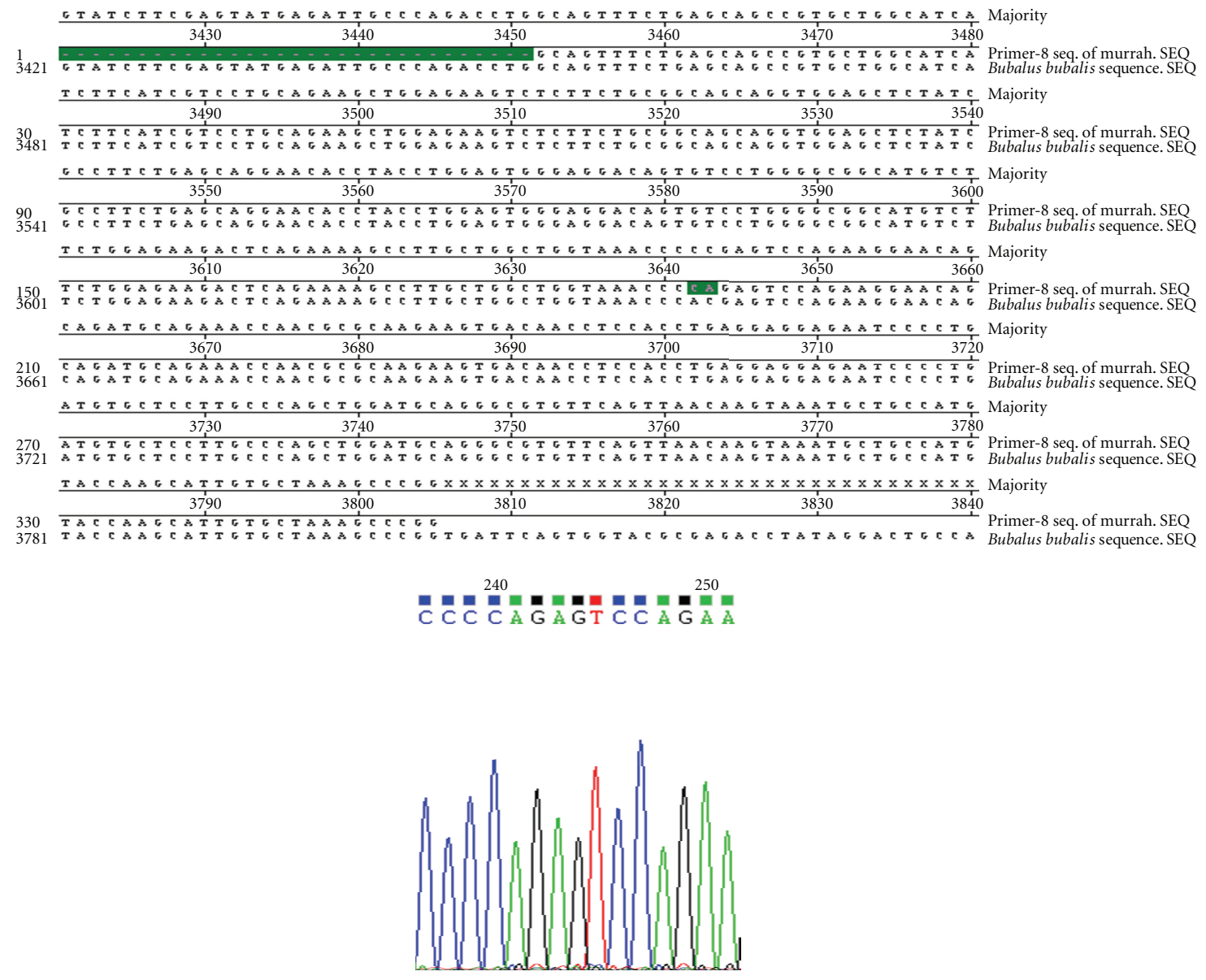

FIGURE 5: Clustal W alignment and chromatograph of contig 3.2 of TLR-4 gene in Murrah (Contd.).

with that of Bubalus bubalis (EU386358) sequence to annotate different exonic regions putatively to identify SNPs in respective region. The partial coding DNA sequence of bubaline TLR-4 gene (exons 1, 2, and 3) was conceptually translated and compared with that of the Bubalus bubalis to detect amino acid changes in buffalo TLR- 4 regions included in present study. The contiguous TLR-4 nucleotide sequence was subjected to Basic Local Alignment Search (BLAST) at NCBI database to determine the sequence homology with the corresponding regions of other species.

\section{Results and Discussions}

The sample genomic DNA was amplified by Polymerase Chain Reaction (PCR). PCR conditions were standardized. The amplified PCR product was checked on $1.5 \%$ agarose to verify the amplification of target region. The amplified sizes were estimated as $165 \mathrm{bp}$ for exon 1, $300 \mathrm{bp}$ for exon 2, $478 \mathrm{bp}$ for exon 3.1, and $409 \mathrm{bp}$ for exon 3.2.

Polymerase Chain Reaction-Restriction Length Polymorphism (PCR-RFLP) analysis of each PCR product was carried out using Dra I, Hae III, Hind III, and Hinf I restriction enzymes for all 102 animals included in this study system. Restriction digestion of amplicon of Exon 1 revealed two fragments of 110 and $55 \mathrm{bp}$ exhibiting monomorphic (BB) pattern in all the animals under study. However, exon 2 of TLR4 gene did not have any cutting site with Dra $I$. Restriction digestion of exon 3.1 resulted in resolution of 5 fragments, identified as AA $(478,350,272,169 \mathrm{bp}), \mathrm{AB}(478$, $350,272,169,74 \mathrm{bp})$, and BB (272, 169, $74 \mathrm{bp})$ genotypes. TLR4-exon 3.2 exhibited AA (409 bp) AB (409, 246,163 bp) and $\mathrm{BB}(246,163 \mathrm{bp})$ genotypes with this restriction enzyme.

PCR-RFLP of exon 1 with Hae III RE yielded two genotypes $\mathrm{AB}(165,122$, and $43 \mathrm{bp})$ and $\mathrm{BB}$ (122 and $43 \mathrm{bp})$. Exons 2 and 3.1 of TLR4 gene did not have any cutting site with Hae III RE. Exon 3.2 exhibited AA (409 and 309 bp), AB $(309,200,142$, and $100 \mathrm{bp})$, and BB (200, 142, and $100 \mathrm{bp})$ genotypes.

PCR-RFLP analysis of TLR4 gene using Hind III restriction enzyme did not reveal any cutting site.

PCR-RFLP analysis of exon 1 of TLR4 gene using Hinf $I$ restriction enzyme yielded two fragments of $110 \mathrm{bp}$ and $55 \mathrm{bp}$ size. No polymorphism was found with respect to Hindf I RE. Exon 2 of TLR4 gene did not have any cutting site with Hinf I RE. The only genotype exhibited by exon 3.1 of TLR-4 was BB with 291 and 187 bp restriction fragment size. For exon 3.2, genotypes with restriction fragment were identified as AA (409, 308, and 292 bp), AB (308, 292, 200, 136 , and $100 \mathrm{bp})$, and $\mathrm{BB}(200,136$, and $100 \mathrm{bp})$. 
$\begin{array}{lcl}\text { EXON } 1 * & & \\ \text { EMBOSS_001 } & 1 \text { MMARARLAAALIPAMAILSCLRTESWDPCVQVR } & 33 \\ & ||||||||||||||+|||||||||||||||| \mid & \\ \text { EMBOSS_001 } & 1 \text { MMARARLAAALIPATAILSCLRTESWDPCVQVRPN } & 35\end{array}$

EXON $3 * *$

EMBOSS_001 56 DFPIGHLRALKELNVAHNFIHSFKLPEYFSNLPNLEHLDLSNNKIQNISH 105

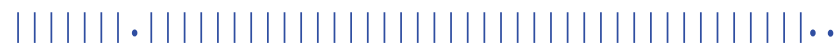

EMBOSS_001 151 DFPIGHLVALKELNVAHNFIHSFKLPEYFSNLPNLEHLDLSNNKIQNIYQ

200

155

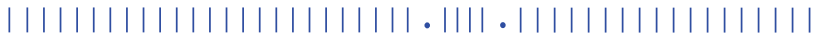

EMBOSS_001 201 EDVKVLHQMetPLLNLSLDLSLNPLDFIEPDTFNEIKLNGLTLRSNFNSL

FIGURE 6: Multiple alignment of conceptualized TLR4 amino acid sequences of Bubalus bubalis (accession number EU 386358) and present study. ${ }^{*}$ In exon 1 amino acid substitution: threonine (T) to methionine (M). ${ }^{* *}$ In exon 3 amino acid substitution: valine (V) to arginine $(\mathrm{R})$, tyrosine $(\mathrm{T})$ to serine $(\mathrm{S})$, glutamine $(\mathrm{Q})$ to histidine $(\mathrm{H})$, and aspartic acid $(\mathrm{D})$ to glycine $(\mathrm{G})$.

The present findings of Murrah buffalo could not be compared with other studies, as no such report on buffalo is available in the literature. In a recent study by Sonawane [6] in the same buffalo herd, three genotypes $A A, A B$, and BB with variable frequencies using Alu I, Bsp $1286 \mathrm{I}$, and BsHKAI restriction enzymes were reported. However, exon 2 in that study was also observed as highly conserved part of the gene. Hence, no cutting site was observed using 7 enzymes (3 REs by Sonawane [6], and 4 in the present study). Sharma et al. [4] reported CC, CG and GG, genotypes in the promoter region (P 226) of Holstein cattle. Wang et al. [5] reported moderate occurrence of polymorphism with AluI in Chinese Simmental, Holstein, and Sanhe cattle.

\section{Analysis of Sequencing Data}

Nucleotide sequencing of amplified fragments of TLR-4 gene of buffalo was performed (Figures 1, 2, 3, 4, and $5)$. The Coding DNA Sequence of bubaline TLR4 gene compared with that of this sequence was compared to the reported sequence of Bubalus bubalis with NCBI accession number EU386358. The sequence obtained for Murrah was compared and aligned custom sequenced using the MegAlian program of DNASTAR software. Amplified regions of the 4 contig regions were custom sequenced by using forward and reverse primers. Sequence data were analysed using chromas (Ver.1.45, http://www.technelysium.com.au/chromas.html). Clustal W multiple alignments with Bubalus bubalis sequence revealed a total of $12 \mathrm{bp}$ changes, one in exon 1 and 11 in exon 3. Multiple alignment revealed a total of 12 mutations: 1 in exon 1 and 11 in exon 3. Out of these 12 mutations, six were nonsynonymous resulting in change in Threonine to Methionine, Valine to Arginine, Tyrosine to Serine, Glutamine to Histidine, and Aspartic Acid to Glycine (at two positions) (Figure 6).

\section{SNP Identification}

Sequence analysis revealed 12 SNPs in the coding (exonic) region of TLR-4 gene given in Table 1 . The Coding DNA Sequences of Murrah TLR-4 gene (Exon 1, 2, and 3) were conceptually translated and compared with those of Bubalus bubalis reported sequences (NCBI Accession number EU386358). At position 75nt of exon 1, only one SNP ( $\mathrm{T}$ to $\mathrm{C}$ ) has been identified which has resulted in a substitution of Threonine to Methionine. Exon 2 did not show any change in base sequence. However, a total of 11 SNPs have been identified in exon 3 at nucleotide positions 311, 315, 316, 318, 386, 401, 411, 551, 555, 636, and 994. Only five of these nucleotide changes result into changes in amino acids leading to nonsynonymous SNPs. In the only report available till date, Sonawane [6] has reported a total of six SNPs, out of which 4 are nonsynonymous, two each in exons 1 and 3. He also did not observe any SNP in exon 2. However, in Holstein cattle, Sharma et al. [4] have reported 3 SNPs: 1 in promoter region (P-226) and 2 in exon 3 (1656 and 2021). Wang et al. [5] identified 1 SNP at nucleotide 1397 in exon 3. Wang et al., 2007 have reported 31 SNPs scattered through the $5^{\prime}$ flanking region to exon 3. Five of these SNPs were coded for amino acid substitution. 
TABLE 1: SNPs identified in TLR-4 gene (Murrah buffaloes).

\begin{tabular}{cccc}
\hline Region & Position & Base change & Amino acid substitution \\
\hline Exon 1 & 75 & C-T & T-M \\
\hline & 311 & A-C & R-V \\
& 315 & A-C & S-Y \\
& 316 & T-C & - \\
& 318 & A-C & H-Q \\
& 386 & C-A & G-D \\
Exon 3 & 401 & G-A & G-D \\
& 411 & A-C & - \\
& 551 & T-G & - \\
& 555 & C-A & - \\
& 636 & T-C & - \\
\hline
\end{tabular}

T: Threonine; M: Methionine; R: Arginine; V: Valine; S: Serine; Y: Tyrosine H: Histidine; Q: Glutamine; G: Glycine; D: Aspartic Acid;

-: means that there was no amino acid substitution.

\section{Sequence Alignment and Homology Across Species}

The contiguous TLR-4 nucleotide sequence was subjected to basic local alignment search tool (BLAST) at NCBI database to know the sequence homology with the corresponding regions of other species. It revealed 97\%, 97\%, 99\%, 98\%, and $80 \%$ homology with Bos indicus, Bos taurus, Ovis aries, Capra hircus, and Homo sapiens respectively. Sequence alignment and homology across species using Basic Local Alignment Search Tool (BLAST) analysis revealed 97\%, 97\%, 99\%, 98\%, and 80\% sequence homology with Bos taurus, Bos indicus, Ovis aries, Capra hircus, and Homo sapiens, respectively.

\section{Conclusion}

In conclusion, nucleotide sequencing of the amplified fragment of TLR-4 gene of Murrah buffalo revealed Twelve SNPs: 1 in exon 1 and 11 in exon 3. Six SNPs were nonsynonymous resulting in change in amino acids. Murrah is an indigenous Buffalo breed, and the presence of the nonsynonymous SNP is indicative of its unique genomic architecture. Sequence alignment and homology across species using Basic Local Alignment Search Tool (BLAST) analysis revealed 97\%, 97\%, $99 \%, 98 \%$, and $80 \%$ sequence homology with Bos taurus, Bos indicus, Ovis aries, Capra hircus, and Homo sapiens, respectively.

\section{Acknowledgment}

The authors are thankful to the Director of the National Dairy Research Institute (Deemed University), Karnal, Haryana, India for providing necessary facilities to carry out this research work.

\section{References}

[1] I. Sabroe, R. C. Read, M. K. B. Whyte, D. H. Dockrell, S. N. Vogel, and S. K. Dower, "Toll-like receptors in health and disease: complex questions remain," Journal of Immunology, vol. 171, no. 4, pp. 1630-1635, 2003.

[2] K. Takeda, T. Kaisho, and S. Akira, “Toll-like receptors," Annual Review of Immunology, vol. 21, pp. 335-376, 2003.

[3] S. N. White, K. H. Taylor, C. A. Abbey, C. A. Gill, and J. E. Womack, "Haplotype variation in bovine Toll-like receptor 4 and computational prediction of a positively selected ligandbinding domain," Proceedings of the National Academy of Sciences of the United States of America, vol. 100, no. 18, pp. 10364-10369, 2003.

[4] B. S. Sharma, I. Leyva, F. Schenkel, and N. A. Karrow, "Association of toll-like receptor 4 polymorphisms with somatic cell score and lactation persistency in Holstein bulls," Journal of Dairy Science, vol. 89, no. 9, pp. 3626-3635, 2006.

[5] X. Wang, S. Xu, X. Gao, H. Ren, and J. Chen, "Genetic polymorphism of TLR4 gene and correlation with mastitis in cattle," Journal of Genetics and Genomics, vol. 34, no. 5, pp. 406412, 2007.

[6] Gokul S. Sonawane, Molecular characterization of toll-like receptor-4 (TLR-4) gene in Murrah buffalo (Bubalus bubalis), M.S. thesis, N.D.R.I., Deemed University, Karnal, India, 2009.

[7] J. Sambrook, E. F. Fritsch, and T. Maniatis, Molecular CloningA Laboratory Manual, vol. 3, Cold Spring Harbor Laboratory Press, 2nd edition, 1989. 

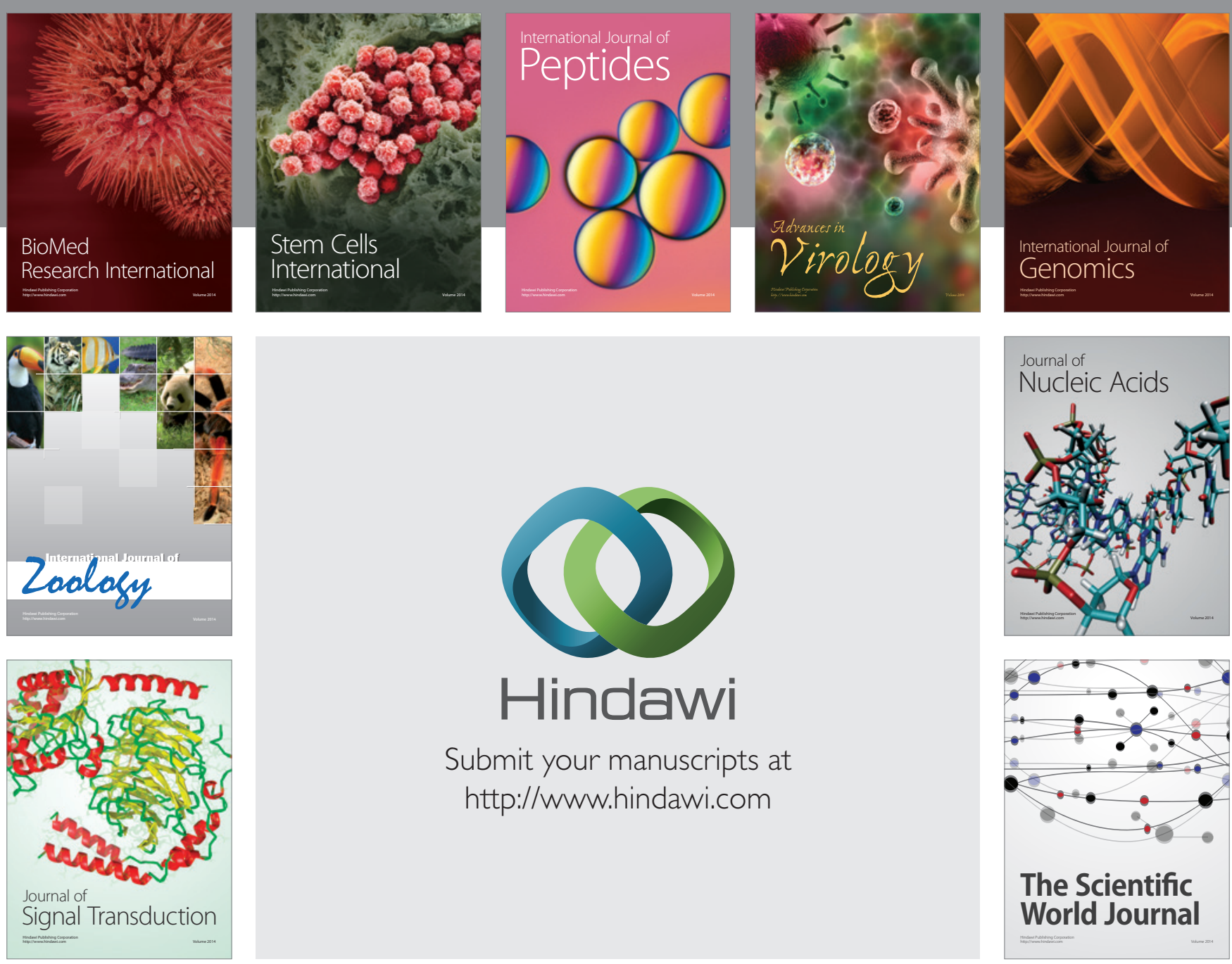

Submit your manuscripts at

http://www.hindawi.com
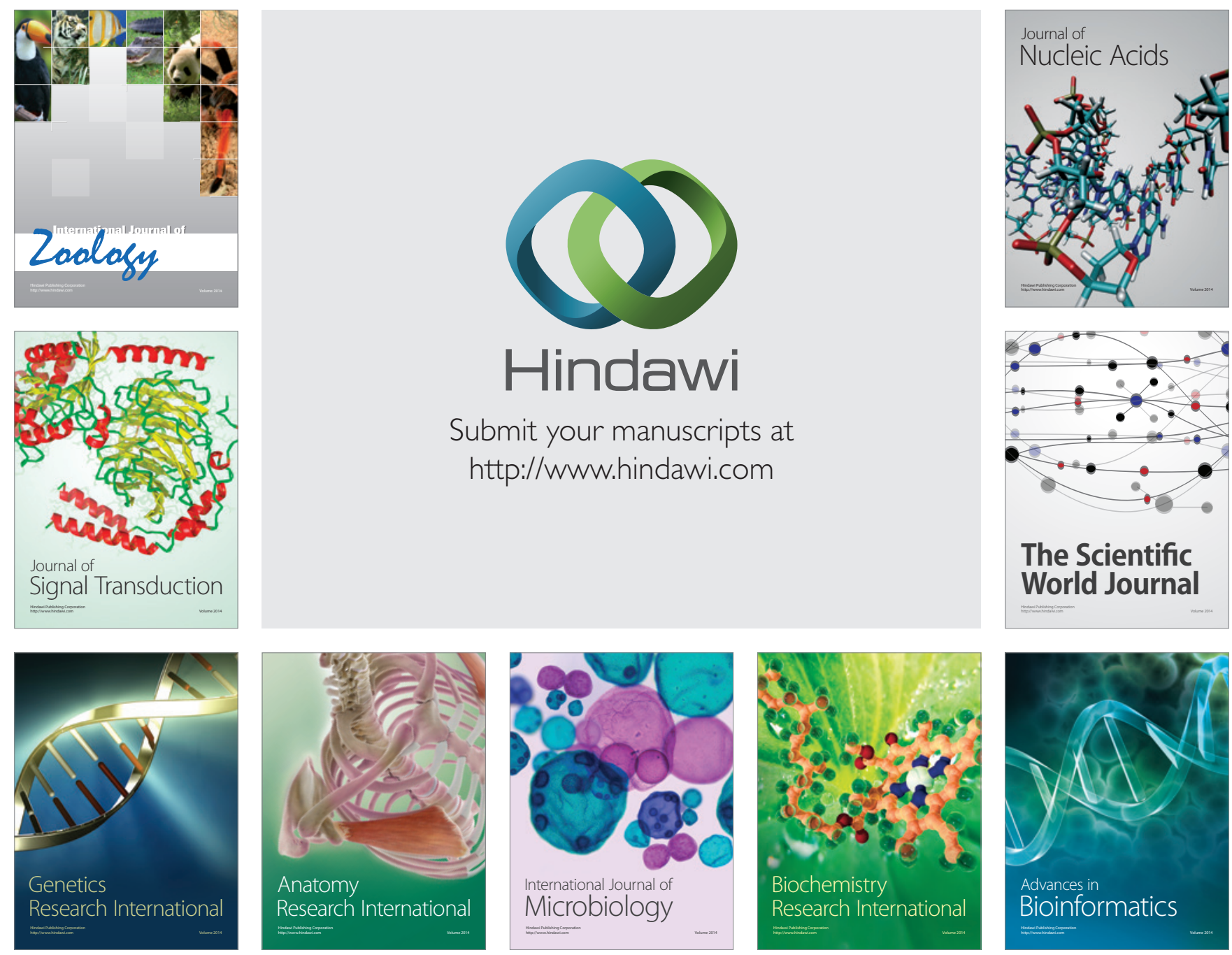

The Scientific World Journal
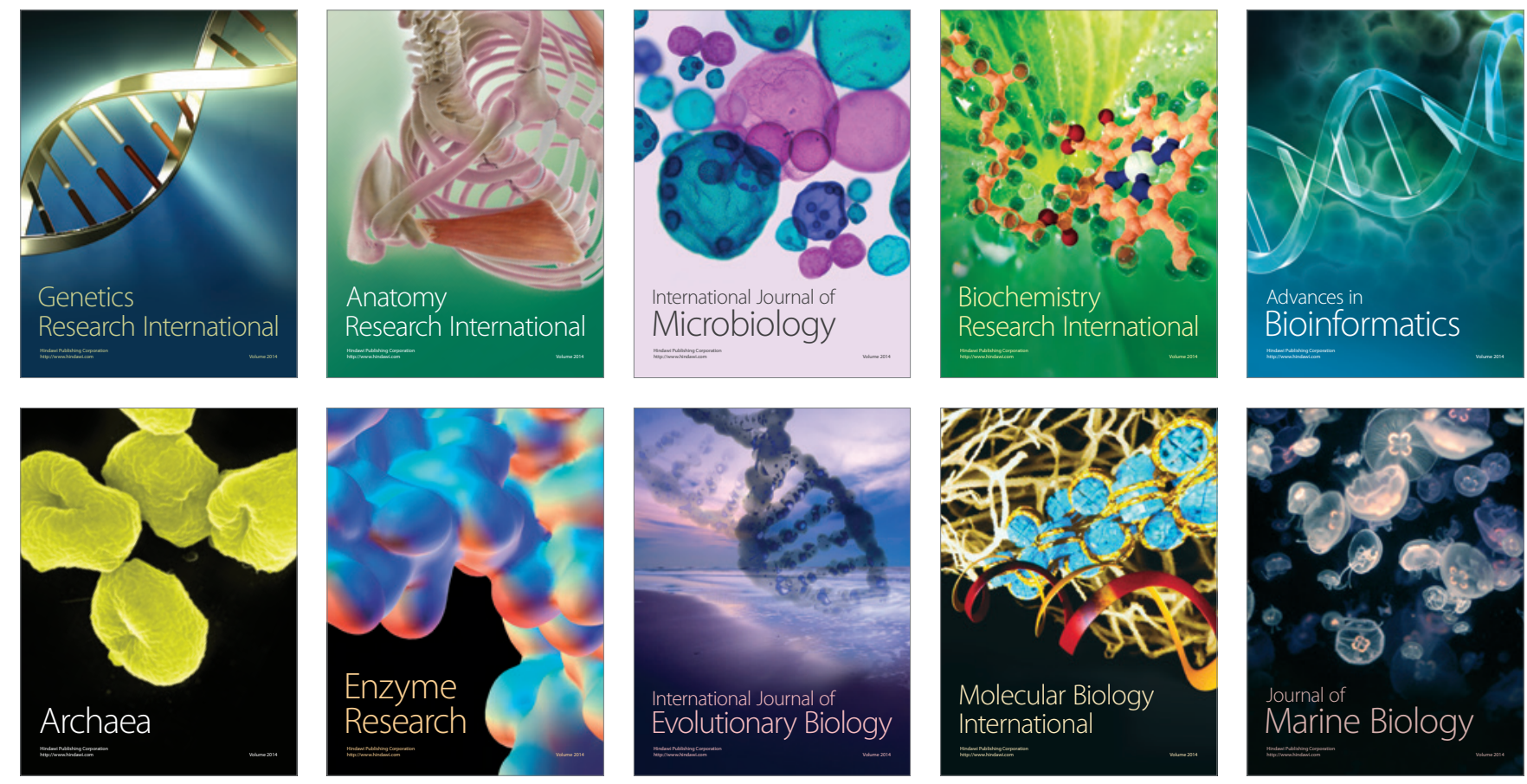